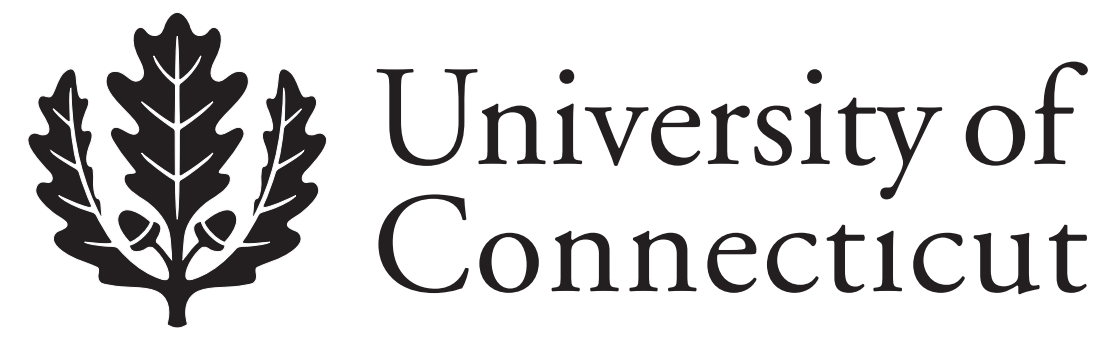

Department of Economics Working Paper Series

\title{
Interstate Risk Sharing in Germany: 1970-2006
}

\section{Ralf Hepp}

Fordham University

Jürgen von Hagen

University of Bonn and Indiana University

Working Paper 2010-13

October 2010

341 Mansfield Road, Unit 1063

Storrs, CT 06269-1063

Phone: (860) 486-3022

Fax: (860) 486-4463

http://www.econ.uconn.edu/

This working paper is indexed on RePEc, http://repec.org/ 


\begin{abstract}
We study the channels of interstate risk sharing in Germany for the time period 1970 to 2006, estimating the degrees of smoothing of a shock to a states gross domestic product by factor markets, the government sector, and credit markets, respectively. Within the government sector, we pay special attention to Germany's fiscal equalization mechanism. For pre-unification Germany, we find that about 19 percent of a shock are smoothed by private factor markets, 50 percent are smoothed by the German government sector, and a further 17 percent are smoothed through credit markets. For the post-reunification period, 1995 to 2006, the relative importance of the smoothing channels has changed. Factor markets contribute around 50.5 percent to consumption smoothing. The government sectors role is diminished: it smoothes around 10 percent of a shock. Fiscal equalization only plays a very small role for consumption smoothing in Germany.
\end{abstract}

Journal of Economic Literature Classification: H77, E63, F42

Keywords: Regional Risk-sharing, Factor Markets, Consumption Smoothing, Fiscal Federalism

This paper was partially written while Ralf Hepp was visiting the University of Connecticut 


\section{Introduction}

The stability of an economic union such as a federation or a large state depends crucially on its capacity to deal with idiosyncratic shocks to regional output. In a world with perfect asset markets, such shocks do not matter much, as consumers in all regions of the union can insure themselves against them. With imperfect asset markets, however, other channels of interregional risk sharing move to the forefront. Apart from capital markets, labor markets provide opportunities for risk sharing, if workers residing in one region can work and earn incomes in another region. Credit market can provide opportunities for borrowing and lending across regions and, thus, consumption smoothing. Finally, the public sector can contribute to interregional risk sharing if a negative shock to the income of one region triggers transfers payments either horizontally from other regions or vertically from the central government offsetting the impact of the original shock.

Empirical research on interregional risk sharing has concentrated mostly on the US and Canada. ${ }^{1}$ In an influential study, Asdrubali et al. (1996) [henceforth, ASY] measure the (relative) importance of the three channels of risk sharing among the states of the US. They find that, for the period from 1963 to 1990, 39 percent of idiosyncratic shocks to the gross state product of US states are smoothed by capital markets, 13 percent by federal fiscal transfers, and 23 percent by credit markets. $^{2}$ Their results were largely confirmed by Mélitz and Zumer (1998) who also perform a number of methodological robustness checks. Athanasoulis and van Wincoop (1998) disregard the potential of credit markets for risk sharing and find that capital markets and the public sector smooth 35 and 10 percent of state-specific shocks in the US, respectively. Del Negro (2002) points out that these estimates might be upwards biased due to measurement errors in state-level data.

Bayoumi and Klein (1997) use Canadian provincial trade-balance data to determine the degree risk sharing within Canada and between Canada and other OECD countries. ${ }^{3}$ They find a high degree of risk sharing among Canadian provinces but little risk sharing across international borders. In a similar vein, Crucini (1999) finds substantial risk sharing among Canadian provinces and U.S. States; but a much lower degree of risk sharing between these and other countries. Ostergaard et al. (2002) also use U.S. and Canadian data to focus on the consumption-smoothing role of credit markets. They find that both U.S. states and Canadian provinces achieve some, but not full consumption smoothing through credit markets. Del Negro (2002) also questions findings of considerable interstate risk sharing in some of the earlier literature due to lack of corrections for measurement errors. He extends the Hess and Shin (1998) data and uses a factor model to determine the degree of risk-sharing among U.S. states. He finds that the quantity anomaly holds for U.S. states after correcting for measurement error in the consumption and output data.

The capacity to provide interregional risk sharing has also been investigated for several other countries. ${ }^{4}$ Mélitz and Zumer (1998) find that the degree of risk sharing provided by capital mar-

\footnotetext{
${ }^{1}$ A closely related literature in international finance deals with consumption and output risk-sharing at the international level. Contrary to theoretical predictions, the empirical international literature a lack of consumption risksharing: cross-border consumption correlations are typically lower than the corresponding output correlations. This empirical regularity has been dubbed the "quantity anomaly" [see, for example, Backus et al. (1992), Baxter and Crucini (1993), Obstfeld (1994)]. Contrary to most other studies, Hess and Shin (1998) find that the quantity anomaly is present at the national level in the US as well.

${ }^{2}$ Asdrubali and Kim (2004) find similar results for US states; however, when they look at OECD countries and at the EU15, the results are markedly different: Capital markets and international transfers play almost no role, only credit markets do and they contribute about 22 percent to consumption smoothing.

${ }^{3}$ As pointed out by Sorensen and Yosha (2000), Bayoumi and Klein's estimation does not distinguish between the three separate smoothing channels.

${ }^{4}$ Following a different methodological approach, van Wincoop (1995) uses data on Japanese regions and finds that the
} 
kets in the UK and Italy is similar to the US, while risk sharing operating through the public sector and credit markets is very low or even nonexistent. There are also a few studies focusing on risksharing in Germany. Büttner $(1999,2002)$ uses the methodology of ASY, but focuses exclusively on the effectiveness of the fiscal system of West Germany to smooth state income, not state output, for the 1970 to 1997 time period. The fiscal channel considers the smoothing effects of fiscal transfers mandated by the fiscal equalization system, of federal taxes, of contributions and transfers from the mandatory pension system, and of the unemployment insurance. Büttner finds that the German fiscal system smoothes only around 15 percent of a shock to state income, with about 6 percent coming from the fiscal equalization system. Kellermann (2001) looks at German data for the same time period, 1970 to 1997. However, she distinguishes between pre- and post-unification data. The sample from 1970 to 1990 ("pre-unification”) includes only the 10 states of the former West Germany; the sample from 1992 to 1997 ("post-unification”) includes all 16 states of unified Germany. She finds that the fiscal system smoothes over 40 percent of shocks to state income. Additionally, private capital markets smooth out about 30 percent of such shocks. In the post-unification data, the role of private capital markets in consumption smoothing is drastically reduced (to 7 and 1 percent, respectively). ${ }^{5}$ Kellermann does not consider ex-post smoothing through credit markets. In a more recent study, Jüßen (2006) investigates risk sharing in post-unification Germany, using a modified version of ASY's methodology. His data set is very disaggregated and comprises 271 labor market regions. Looking at data for the years 1995 to 2002, the study has two main empirical findings. First, estimation of risk-sharing properties by using ordinary least squares (OLS) as well as nonparametric density estimation suggests that private capital markets almost completely smooth out region-specific income shocks, with the German fiscal system providing no additional insurance. The study's OLS results even seem to suggest that the fiscal system has a destabilizing effect on regional incomes.

This paper provides new and comprehensive empirical evidence on the issue for Germany. One particular focus of our study is the fiscal equalization mechanism. Germany, like Canada and in contrast to the United States, has an explicit, formula-based mechanism for fiscal equalization, the Länderfinanzausgleich (LFA), and this is a particularly interesting case. The legal framework for the equalization mechanism is based on the constitutional principle that the states should guarantee their citizens similar living standards throughout the federation. Its primary focus is, therefore, on redistribution. However, as the literature suggests, fiscal transfer mechanisms may also play a stabilizing role implicitly. Our focus in this paper is on the stabilization properties of factor and credit markets in addition to those of the fiscal system. To the best of our knowledge, this is the first paper on Germany that considers all three smoothing channels simultaneously and relies on a sufficiently long post-unification data set.

A second focus of this paper is the comparison of risk sharing before and after German unification. From 1970 to 1994, only states in the former West Germany were part of the LFA. Since 1995, however, all German states have been included in the LFA. One of the key differences between the two time periods is the increased heterogeneity in per capita incomes that came with the inclusion of the significantly poorer East German states in 1995. Another important difference is that, after unification, channeling huge, permanent transfers from West to East Germany has become a prime function of the German fiscal system. With the integration of East Germany, the average size of transfers in the fiscal equalization mechanism also increased substantially. In view of this, we ask how unification has affected the degree of risk sharing among the states of the German federation.

correlation of consumption growth rates within Japan is similar to that on the international level.

${ }_{5}^{5}$ The results in these two papers differ mainly due to differences in their definitions of state income and disposable state income as well as differences in the time period considered. 
In our estimations, we find that, for the time period 1970 to 1994, the government sector (including social security, tax redistribution, and the fiscal equalization mechanism) was the most important smoothing channel with over 50 percent consumption smoothing. Slightly less than five percent of the smoothing effect came from the fiscal equalization mechanism. Factor markets were the other important channel of risk sharing, contributing around 19 percent. Finally, credit markets contributed another 17 percent to risk sharing. For the post-reunification period, 1995 to 2006, the relative importance of the three channels has changed. In the complete sample, factor markets contribute around 50.5 percent to risk sharing, and credit markets contribute another 17.5 percent. The government sector's role is diminished: It smoothes around 10 percent of a shock. For this period, we also split our sample between West and East German states. In West Germany, 63 percent of idiosyncratic income shocks are smoothed out by factor markets; and another 15 percent by the government sector. In East Germany, factor markets smooth about 34.5 percent of the volatility in state GDP, the government sector about 19 percent, and another 18 percent are smoothed by credit markets.

The remainder of this paper is structured as follows. In section 2, we describe the empirical methodology we use to investigate the risk sharing channels in Germany. Section 3 provides a detailed description of our data and data sources. Our main empirical results are presented and interpreted in section 4 . Section 5 concludes.

\section{Data}

As argued above, our study focuses on estimating the importance of factor markets, the German government sector, and credit markets in consumption smoothing at the state level in Germany. In this section, we provide a more detailed description of the variables used in the panel data analysis. We construct two different data sets: The first consists of annual data of the 10 West German states (excluding West-Berlin) from 1970 to 1994. Because of our special focus on the fiscal equalization mechanism (Länderfinanzausgleich) in Germany, we choose the year 1995 as the cut-off year for our sample. The year 1995 was the first year when the "new" states of East Germany where fully integrated into the fiscal equalization mechanism. Hence, the second data set contains annual data of all 16 German states covering the period from 1995 to 2006. Both panel data sets are balanced.

First, we construct real gross domestic product per capita at the state level from our original data. For the 1970-1994 period, we have state-level data on aggregate real gross domestic product. The real GDP values in our original data are constructed by using a common national, rather than statespecific, GDP deflator with base year $1991 .{ }^{6}$ We then divide these aggregate values by the population of the state to get real per capita values. Second, we define real state income in a way fairly standard in this literature, namely as the sum of real net state income at factor prices per capita and all real tax revenues (before redistribution) with tax incidence within a state's boundaries. ${ }^{7}$ Aggregate real net state income at factor prices is provided in the data, and we obtain real values for the tax revenues by using the GDP deflator described previously. At this point, it is important to understand how the German fiscal system is structured. First, all taxes are collected by the states rather than the federal government. These taxes therefore include federal (Bundessteuern), state (Landessteuern), and local taxes (Gemeindesteuern), as well as taxes that

\footnotetext{
${ }^{6}$ von Hagen and Neumann (1994) show that real exchange rate variance among German states has been very low since the 1970s, i.e., price level changes between German states have been very similar. Hence, the use of a common GDP deflator should not be problematic.

${ }^{7}$ Net state income at factor prices here corresponds to net national income at factor prices in national accounting data.
} 
are shared among all three levels of government, so-called Gemeinschaftsteuern. Gemeinschaftsteuern include important taxes like value added tax revenue, corporate income tax and personal income tax revenue. When constructing real state income per capita, we add the total tax incidence of these taxes, rather than only the share that remains with the state and local governments, since this more appropriately reflects the financial strength of a state.

We construct several different versions of what we call real disposable state income per capita in order to be able to distinguish the role of the Länderfinanzausgleich and its components from other elements of the German fiscal system. The variable $d s i_{n}$ is defined as disposable income of private households plus the tax revenue that remains within the state and is not transferred to the federal and/or other state governments at stage $n .{ }^{8}$ For example, $d s i_{4}$ contains the disposable income of private households (after the contributions to and benefits from the social security system) and the total tax revenue ${ }^{9}$ remaining within the state before the fiscal equalization mechanism (LFA) and. We then define a new disposable state income variable after each step of LFA. As prescribed by law, Germany's fiscal equalization mechanism is conducted in three stages. At the first stage, VAT revenue is redistributed to reduce the variation in per capita VAT receipts among states. States with higher than national average VAT revenue per capita make transfer payments to states with lower than national average VAT revenue per capita in order to push either state closer to the preredistribution national average per capita revenue. ${ }^{10}$ At the second stage, states make transfer payments amongst each other based on a more comprehensive measure of a state's resource needs and tax capacity. At the third and last stage, the federal government provides additional federal grants (Bundesergänzungszuweisungen) to further narrow differences in tax capacity between states. After the last stage of the fiscal equalization mechanism, the real disposable state income per capita, $d s i_{1}$, includes the state and local share of VAT revenue that remains within the state, state-to-state transfers (if applicable), federal grants (again, if applicable), state taxes (Landessteuern), and net local taxes (Gemeindesteuern). In other words, the difference ( $s i-d s i_{1}$ ) can be interpreted as the combined effects of the social security system, transfer of federal (shares of) taxes, and the fiscal equalization mechanism. Finally, we define real state consumption per capita $C_{i}$ as the sum of real private and public per-capita consumption in state $i$.

Data on gross domestic product, net national income at factor prices, population, private and public consumption for 1970-1994 was provided to us by the Statistisches Landesamt BadenWürttemberg (1998). For the period 1995-2006, we use national accounting data provided online by the German federal and state statistical offices (Statistisches Landesamt Baden-Württemberg (2008)) which was computed using a standardized European Union methodology (ESVG1995). Data on tax revenues before and after redistribution come from publications of the German federal statistical office (Statistisches Bundesamt (1977, 1989, 2000)). Data on VAT redistribution and state-to-state transfers is from annual publications of the Bundesrat (Bundesrat). Tax data for the years 1995 to 2002 was provided by the Statistical Office of Baden-Württemberg, data for the years 2003 to 2006 is available online from the German Federal Statistical Office (Statistisches Bundesamt). As previously described, in the data set covering the years 1970 to 1994, all nominal variables are converted into real values with the aforementioned national GDP deflator with base year 1991, and then divided by the state's population to get per capita values. In contrast, nominal

\footnotetext{
${ }^{8}$ In the German official data, disposable income of private households is defined as household income after taxes and social security payments or receipts.

${ }^{9}$ At this point, all federal taxes, and the federal share of income and local taxes are netted out here.

${ }^{10}$ A more detailed description of the fiscal equalization mechanism in Germany can be found in Hepp and von Hagen (2001).
} 
and real values for a state's gross domestic product, its private and public consumption are available for the 1995 to 2006 time period. They are converted from nominal to real values by (different) state-specific deflators for each of the three series. For the conversion of all other variables into real values, we use the state-specific GDP deflator with base year 1991.

\section{Methodology}

We follow the framework of Asdrubali et al. (1996) to investigate the importance of different channels for risk sharing at the state level in Germany. We focus on three main channels, i.e., factor markets ${ }^{11}$, the government sector, and private credit markets. ${ }^{12}$ For the government sector, we distinguish between the effect of individual components of the German tax and transfer system and all of them combined. ${ }^{13}$ Following Asdrubali et al., we start from the following identity,

$$
g d p_{i}=\frac{g d p_{i}}{s i_{i}} \frac{s i_{i}}{d s i_{i}} \frac{d s i_{i}}{c_{i}} c_{i}
$$

where $g d p_{i}$ is the gross domestic product of state $i, s i_{i}$ is state income, $d s i_{i}$ is disposable state income, and $c_{i}$ is state consumption. ${ }^{14}$ We then perform a period-by-period decomposition of the cross-sectional variance in state gross domestic product. To do that, we take logs and differences of equation , multiply both sides by $\Delta \log (g d p)$ and take expectations to obtain

$$
\begin{aligned}
\operatorname{var}(\Delta \log (g d p))= & \operatorname{cov}(\Delta \log (g d p), \Delta \log (g d p)-\Delta \log (s i)) \\
& +\operatorname{cov}(\Delta \log (g d p), \Delta \log (s i)-\Delta \log (d s i)) \\
& +\operatorname{cov}(\Delta \log (g d p), \Delta \log (d s i)-\Delta \log (c)) \\
& +\operatorname{cov}(\Delta \log (g d p), \Delta \log (c))
\end{aligned}
$$

Dividing both sides by the variance of $\Delta \log (g d p)$, we get:

$$
1=\beta_{F}+\beta_{G}+\beta_{C}+\beta_{U}
$$

where the $\beta$ 's are ordinary least squares (OLS) estimates. Here, $\beta_{F}$ is the OLS estimate of the slope in the regression of $(\Delta \log (g d p)-\Delta \log (s i))$ on $\Delta \log (g d p)$. Full risk sharing through factor markets alone corresponds to $\beta_{F}=1$, implying that state income si is unaffected by changes in state gross domestic product $g d p$; i.e. there is no co-movement of state income and state gross domestic product. In contrast, $\beta_{F}=0$ implies perfect co-movement of state income and state gross domestic product; in this case, factor markets do not contribute to consumption smoothing. The

\footnotetext{
${ }^{11}$ In contrast to Asdrubali et al. (1996) who call the smoothing channel from state GDP to state income "capital markets", we call it "factor markets The reason is that in addition to cross-ownership of productive assets, many workers are working in neighboring states (this is especially true for city states and their neighbors), contributing to the neighboring state's GDP while generating net factor income for their state of residence which is included in state income.

${ }^{12}$ For a detailed description of the mechanics of each of these smoothing channels, see Asdrubali et al. (1996).

${ }^{13}$ These components include social security, unemployment and pension benefits/payments, tax redistribution, and the components of the German Länderfinanzausgleich (redistribution of state share of VAT revenue, state-to-state transfers, and federal grants).

${ }^{14}$ A more detailed description of these variables can be found in section 2.
} 
coefficients $\beta_{G}$ and $\beta_{C}$ are interpreted similarly. $\beta_{U}$ is the "unsmoothed" part of the variance of state gross domestic product, i.e., that part which fully affects the consumption of a state's residents. ${ }^{15,16}$

We implement this framework by separately running the following four panel regressions:

$$
\begin{aligned}
\Delta \log \left(g d p_{i t}\right)-\Delta \log \left(s i_{i t}\right) & =\alpha_{F, t}+\beta_{F} \Delta \log \left(g d p_{i t}\right)+\varepsilon_{F, i t} \\
\Delta \log \left(s i_{i t}\right)-\Delta \log \left(d s i_{1, i t}\right) & =\alpha_{G, t}+\beta_{G} \Delta \log \left(g d p_{i t}\right)+\varepsilon_{G, i t} \\
\Delta \log \left(d s i_{1, i t}\right)-\Delta \log \left(c_{i t}\right) & =\alpha_{C, t}+\beta_{C} \Delta \log \left(g d p_{i t}\right)+\varepsilon_{C, i t} \\
\Delta \log \left(c_{i t}\right) & =\alpha_{U, t}+\beta_{U} \Delta \log \left(g d p_{i t}\right)+\varepsilon_{U, i t}
\end{aligned}
$$

where the cross-sectional dimension is states of the German Federal Republic and $\alpha_{\square t}$ are time fixed effects. They are included to capture shocks to the growth rate of aggregate (national) gross domestic product.

In a second and third set of regressions, we sharpen the focus on the risk sharing effects of the various components of the German government sector. For that purpose, we define disposable state income in different ways ${ }^{17}$ : as disposable state income after transfer of federal (share of) taxes and social security, but before any transfer payments/receipts triggered by the German Länderfinanzausgleich have been made ( $\left.d s i_{4}\right)$; and as disposable state income after these transfers have taken place $\left(d s i_{1}\right)$. For this scenario, we run the following five panel regressions:

$$
\begin{gathered}
\Delta \log \left(g d p_{i t}\right)-\Delta \log \left(s i_{i t}\right)=\alpha_{F, t}+\beta_{F} \Delta \log \left(g d p_{i t}\right)+\varepsilon_{F, i t} \\
\Delta \log \left(s i_{i t}\right)-\Delta \log \left(d s i_{4, i t}\right)=\alpha_{G 1, t}+\beta_{G 1} \Delta \log \left(g d p_{i t}\right)+\varepsilon_{G 1, i t} \\
\Delta \log \left(d s i_{4, i t}\right)-\Delta \log \left(d s i_{1, i t}\right)=\alpha_{G 2, t}+\beta_{G 2} \Delta \log \left(g d p_{i t}\right)+\varepsilon_{G 2, i t} \\
\Delta \log \left(d s i_{1, i t}\right)-\Delta \log \left(c_{i t}\right)=\alpha_{C, t}+\beta_{C} \Delta \log \left(g d p_{i t}\right)+\varepsilon_{C, i t} \\
\Delta \log \left(c_{i t}\right)=\alpha_{U, t}+\beta_{U} \Delta \log \left(g d p_{i t}\right)+\varepsilon_{U, i t}
\end{gathered}
$$

Finally, when we also distinguish disposable state income after each of the three stages of the German Länderfinanzausgleich, we run the following set of regressions:

$$
\begin{gathered}
\Delta \log \left(g d p_{i t}\right)-\Delta \log \left(s i_{i t}\right)=\alpha_{F, t}+\beta_{F} \Delta \log \left(g d p_{i t}\right)+\varepsilon_{F, i t} \\
\Delta \log \left(s i_{i t}\right)-\Delta \log \left(d s i_{4, i t}\right)=\alpha_{G 1, t}+\beta_{G 1} \Delta \log \left(g d p_{i t}\right)+\varepsilon_{G 1, i t} \\
\Delta \log \left(d s i_{4, i t}\right)-\Delta \log \left(d s i_{3, i t}\right)=\alpha_{G 2.1, t}+\beta_{G 2.1} \Delta \log \left(g d p_{i t}\right)+\varepsilon_{G 2.1, i t} \\
\Delta \log \left(d s i_{3, i t}\right)-\Delta \log \left(d s i_{2, i t}\right)=\alpha_{G 2.2, t}+\beta_{G 2.2} \Delta \log \left(g d p_{i t}\right)+\varepsilon_{G 2.2, i t} \\
\Delta \log \left(d s i_{2, i t}\right)-\Delta \log \left(d s i_{1, i t}\right)=\alpha_{G 2.3, t}+\beta_{G 2.3} \Delta \log \left(g d p_{i t}\right)+\varepsilon_{G 2.3, i t} \\
\Delta \log \left(d s i_{1, i t}\right)-\Delta \log \left(c_{i t}\right)=\alpha_{C, t}+\beta_{C} \Delta \log \left(g d p_{i t}\right)+\varepsilon_{C, i t} \\
\Delta \log \left(c_{i t}\right)=\alpha_{U, t}+\beta_{U} \Delta \log \left(g d p_{i t}\right)+\varepsilon_{U, i t}
\end{gathered}
$$

\footnotetext{
15 Alternatively, as described in ASY, the coefficients represent the fraction of shocks to a state's GDP smoothed by a particular channel. For example, $\beta_{\mathrm{F}}=0.43$ means that 43 percent of a shock to a state's GDP is smoothed by factor markets. In our paper, we would sometimes describe that as "43 percent risk sharing".

${ }^{16}$ As in Asdrubali et al. (1996), our coefficient estimates are not restricted to be positive. A negative coefficient implies dis-smoothing of the respective channel.

${ }^{17}$ A more detailed description of the definitions of disposable state income can be found in section 2 and in footnote 8 .
} 
where time fixed effects $\alpha_{\square, t}$ are included again. The $N$ different $d s i_{n}$-terms represent disposable state income after a particular component of the government sector has been taken into account.

Given the nature of our data, several econometric issues need to be addressed before estimating equations, , and . We find evidence for panel-specific heteroskedasticity and contemporaneous correlation across panels in the error matrix. Furthermore, the error terms appear to be serially correlated. In order to deal with these issues, Asdrubali et al. (1996) use feasible generalized least squares (FGLS) in their equation-by-equation estimation. According to Beck and Katz (1995, 1996), it is problematic to apply FGLS to this type of economic data, however. Their Monte Carlo simulations show that standard errors are seriously underestimated using FGLS, thereby providing overconfidence in the significance of the estimated parameters. Furthermore, the correction for contemporaneously correlated errors requires that the number of years $T$ in a sample is at least as large as the number of cross-sectional units $N$. This requirement is not fulfilled for some of our sub-samples. And even for the full sample, each element of the covariance matrix of the errors would be estimated based on very few observations. For these reasons, Beck and Katz suggest the use of an ordinary least squares approach with panel-corrected standard errors (PCSE) instead. Their Monte Carlo simulations show that the error terms estimated in this way are very accurate, even when the error structures in the panel are complicated. Given the presence of panel-specific heteroskedasticity, cross-sectional and serial correlation in our data, our preferred approach is therefore to use ordinary least squares estimation with panel-corrected standard errors (PCSE) as introduced by Beck and Katz (1995).

\section{Results}

In this section, we present and interpret the results from estimating the regressions, , and, using ordinary least squares with panel-corrected standard errors (PCSE). We will also estimate these equations by interacting our explanatory variable $\Delta \log \left(g d p_{i t}\right)$ with a dummy variable for city states and small states, respectively. The dummy variable city ${ }_{i}$ equals one, if a state is a city state, and zero otherwise. The dummy variable small $i$ equals one if a (non-city) state's economic size (measured by absolute GDP) is relatively small, and zero otherwise. ${ }^{18}$. These dummies indicate the additional degree of consumption smoothing obtained by small and city states, respectively. They and allow us to test whether or not city states and small states benefit from more risk sharing than the large states. Our regression setup in is similar to that in Asdrubali et al. (1996). We distinguish between the following channels of consumption smoothing here: factor markets ( $\left.\beta_{F}\right)$, the government sector $\left(\beta_{G}\right)$, credit markets $\left(\beta_{C}\right)$, and the unsmoothed part $\left(\beta_{U}\right)$.

In table 1, we present the results for the sample period 1970 to 1994, which includes only the ten states of West Germany. We start with estimating the regressions one by one. The most effective consumption smoothing channel is the government sector which smoothes about 54 percent of the volatility of GDP, followed by factor markets with almost 20 percent. The consumption smoothing effect of credit markets is statistically significant at about 17 percent. About 9 percent of GDP volatility is not smoothed. As explained earlier, consumption smoothing by the government sector is achieved here by a combination of taxation, social security contributions/benefits, and the fiscal equalization mechanism. Next, we investigate consumption smoothing through the government sector more closely by considering disposable state income before the fiscal equalization mechanism separately (eq. ). We find that taxation and social security contributions/benefits

${ }^{18}$ For a list of states and their categorization, see table 5. 
contribute about 50 percent to consumption smoothing. The coefficient for the fiscal equalization mechanism is at about five percent, but is not statistically significant. However, further investigation of the individual components of the fiscal equalization mechanism (eq.) reveals that state-to-state transfers contribute about 5 percent to consumption smoothing, and redistribution of VAT revenue another 3.6 percent. The coefficient on federal grants is negative (but statistically not significant), implying a destabilizing role of federal grants.

Given the special treatment of city states in the fiscal equalization mechanism and the heterogeneity of the size of German states, we control for both city states and small states. The results are presented in columns 4 to 6 in table 1. The results from a modified version of equation (6) show that the importance of different channels of consumption smoothing is independent of state size with only a few exceptions. ${ }^{19}$ Similar to the previous results, credit markets contribute around 17.5 percent of consumption smoothing for all states. The contribution of factor markets is smaller for large and city states with about 12.4 percent, but larger for small states with about 25.1 percent. Splitting the fiscal system into the transfer of federal tax (share)/social security and the components of the fiscal equalization mechanism reveals that the former is the main consumption smoothing channel. Of the components of the fiscal equalization mechanism' VAT revenue distribution and state-to-state transfers contribute about four and five percent to consumption smoothing, respectively, independent of state size. Federal grants seem to be marginally destabilizing for large and city states, and significantly so for small states with about negative six percent.

We now turn our focus to data from the post-unification period 1995 to 2006. First, we will consider the full sample including all 16 German states. As can be seen in table 2, both factor and credit markets contribute significantly to consumption smoothing with 50.5 and 17.5 percent, respectively. The government sector's contribution is only around ten percent with no contribution from the fiscal equalization mechanism, however. Thus, unification has reversed the role of markets and the government in providing consumption smoothing. Overall, approximately 21 percent of regional shocks are unsmoothed, much more than in Germany before unification. We also ran regressions with interactive explanatory variables controlling for state size. In the last column we report the $x^{2}$ statistic testing for joint significance of the coefficients of the interactive variables for small and city states together of these modified regressions. Only the smoothing effects of state-to-state transfers differ between large states and all other states.

Given the stark economic differences between West and East German states and the ongoing integration process of former East Germany into West Germany, we divide our sample and look at both sub-sets of states separately. In doing so, we now measure the degree of consumption smoothing for East German states around an average East German level of consumption, and the degree of consumption smoothing for West German states around an average West German level of consumption, allowing for the possibility that the difference between the two reference levels of consumption is driven by other shocks.

Starting with the results for East Germany in table 3, we see that all three channels contribute (statistically significantly) to consumption smoothing. Factor markets contribute with about 34 percent, the government sector with about 20 percent, and credit markets with around 18 percent. About 24 percent of income volatility is unsmoothed. When we further divide the government sector up into its components, we find that only the coefficient for the fiscal equalization mechanism is significant and contributes about 7.6 percent to consumption smoothing. In

\footnotetext{
${ }^{19}$ Regression results for modified versions of equations (4) and (5) are not reported, but are available upon request.
} 
particular, the VAT revenue contributes about five percent to consumption smoothing. Including an interactive dummy variable for Berlin reveals that it is the main benefactor of VAT revenue redistribution (see the $\chi^{2}$ statistic in the last column). ${ }^{20}$

Turning to West Germany for the post-unification period, we see in table 4, that factor markets are by far the most important smoothing channel with a contribution of about 63 percent. The government sector overall contributes merely 16.7 percent, mainly via social security. In fact, the fiscal equalization mechanism does not seem to contribute significantly. Distinguishing by state size (see the $\chi^{2}$ statistic in the last column) does not alter these results. Only state-to-state transfers to small states are less effective than state-to-state transfers to other states. ${ }^{21}$ Interestingly, the share of unsmoothed shocks among the West German states is only 13 percent, which is close to the preunification value and is considerably less than the share of unsmoothed shocks in East Germany.

\section{Conclusion}

Our empirical analysis explores the channels of consumption smoothing, with a special focus on the fiscal equalization mechanism in Germany, using data from 1970 to 2006, and hence covering pre- and post-unification Germany. Several interesting findings emerge. When we focus on the time period 1970 to 1994 , we find that the government sector plays the most important role in smoothing income volatility. Our estimate of 54 percent of consumption smoothing smoothing provided by the government sector is significantly higher than Asdrubali's et al. (1996) result for the US of 23 percent for the 1964 to 1990 time period. At the same time, the contribution of factor markets is about half as big in Germany compared to the US (19.5 percent vs. 39 percent). After 1995, when East Germany is included in our sample, our results indicate that all three channels of consumption smoothing - factor markets, credit markets, and the government sector - contribute significantly. Now, however, factor markets contribute the most to consumptionsmoothing with about 50 percent. Since the post-unification data time period is relatively short, it will be interesting to see whether the factor markets will retain their important role as an consumptionsmoothing channel.

For the entire sample, the contribution of the fiscal equalization mechanism to consumption smoothing is relatively small. Itscontribution is typically less than five percent. Hence, the mechanism contributes little to overall consumption smoothing. Most of the consumption smoothing provided by the public sector is accomplished through the social security system and unemployment insurance.

Earlier studies have pointed out that German unification has changed the nature of Germany's federal fiscal system, which has become a mechanism for large-scale transfers from West to East Germany. Our results show that another effect of this change has been that the public sector lost much of its effectiveness as a risk-sharing device among the West German states, a fact that has been unnoticed so far. While the overall degree of risk-sharing among the West German states has remained the same after unification, most of this is now being provided by factor markets. It is plausible that risk-sharing provided by factor markets puts more emphasis on (regional or sectoral) labor mobility than government provided risk-sharing, and that it leaves households who do not own diversified portfolios of financial assets with less protection against region-specific shocks

\footnotetext{
${ }^{20}$ All East German states fall into the category "small state" except Berlin, which is a city state (see table 5).

${ }^{21}$ As a robustness check, all regressions in section 4 were also run with state fixed effects. The results did not differ much quantitatively and not at all qualitatively. We also distinguished between positive and negative shocks to state income to see whether there is asymmetry in the effectiveness of the risk sharing channels. The results were inconclusive, however.
} 
than others. If so, the loss of publicly provided risk-sharing may have added to the dissatisfaction of West German households with the outcomes of German unification.

Similarly, it is plausible to assume that East German households were largely sheltered against region-specific economic shocks under the socialist system. Since German unification, public protection against such shocks in East Germany has been on the order of only 20 percent, while 24 percent of regional shocks are unsmoothed. Thus, these households face more economic risk than before, a fact which may explain why there is much dissatisfaction in spite of the large transfers received in that part of Germany, too. 


\section{References}

Asdrubali, Pierfederico and Soyoung Kim, "Dynamic Risk Sharing in the United States and Europe,” Journal of Monetary Economics 51, 2004, pp. 809-836.

Asdrubali, Pierfederico, Bent E. Sorensen, and Oved Yosha, "Channels of Interstate Risk Sharing: United States 1963-1990,” Quarterly Journal of Economics, 1996, 111 (4), 1081-1110.

Athanasoulis, Stefano G. and Eric van Wincoop, "Risk Sharing within the United States: What Do Financial Markets and Fiscal Federalism Accomplish?”, The Review of Economics and Statistics, November 2001, 83 (4), 688-698.

Backus, David, Patrick Kehoe, and Finn Kydland, “International Real Business Cycles,” Journal of Political Economy, 1992, 100, 745-775.

Baxter, Marianne and Mario Crucini, "Explaining Saving - Investment Correlations,” American Economic Review, June 1993, 83 (3), 416-436.

Baxter, Marianne and Mario Crucini, "Business Cycles and the Asset Structure of Foreign Trade," International Economic Review, November 1995, 36 (4), 821-854.

Bayoumi, Tamim and Michael Klein, “A Provincial View of Economic Integration,” IMF Staff Papers, December 1997, 44 (4), 534-556.

Bayoumi, Tamim and Paul R. Masson, "Fiscal Flows in the United States and Canada: Lessons for Monetary Union in Europe,” European Economic Review 39, 1995, pp. 253-274.

Beck, Nathaniel and Jonathan N. Katz, "What To Do (and Not To Do) with Time-Series CrossSection Data,” American Political Science Review, September 1995, 89 (3), 634-647.

Beck, Nathaniel and Jonathan N. Katz, "Nuisance vs. Substance: Specifying and Estimating TimeSeries-Cross-Section Models,” Political Analysis 6, 1996, pp. 1-36.

Bucovetsky, Sam, "Federalism, Equalization, and Risk Aversion,” Journal of Public Economics, March 1998, 67 (3), 301-328.

Bundesrat, Zweite Verordnung zur Durchf"uhrung des Finanzausgleichsgesetzes im Ausgleichsjahr ...., Drucksache, various years.

Büttner, Thiess, "Regional Stabilization by Fiscal Equalization? Theoretical Considerations and Empirical Evidence from Germany,” 1999. ZEW Mannheim, mimeo.

Büttner, Thiess, "Fiscal Federalism and Interstate Risk Sharing: Empirical Evidence from Germany,” Economics Letters 74, 2002, pp. 195-202.

Crucini, Mario, “On International and National Dimensions of Risk Sharing," Review of Economics and Statistics, February 1999, 81 (1), 73-84.

Del Negro, Marco, “Asymmetric Shocks among U.S. States,” Journal of International Economics 56, 2002, pp. 273-297.

Hepp, Ralf and Jürgen von Hagen, "Regional Risk sharing and Redistribution in the German Federation,” 2001. CEPR Discussion Paper No.2662.

Hess, Gregory and Eric van Wincoop, Intranational Macroeconomics, Cambridge University Press, 2000.

Hess, Gregory and Kwanho Shin, “Intranational Business Cycles in the United States,” Journal of International Economics 44, 1998, pp. 289-313.

Jüßen, Falko, “Interregional Risk Sharing And Fiscal Redistribution in Unified Germany,” Papers in Regional Science, June 2006, 85 (2), 235-255. 
Kellermann, Kerstin, "Stabilization Properties of Interregional Fiscal Flows: Evidence for Germany, 1970-1997,” 2001. University of Fribourg, Center of Public Finance, mimeo.

Kurz, Claudia, "Regional Risk Sharing and Redistribution by the Unemployment Insurance System: The Case of Germany,” 2000. Europa-Universität Viadrina, mimeo.

Lockwood, Ben, “Inter-regional Insurance,” Journal of Public Economics 72, 1999, pp. 1-37.

Obstfeld, Maurice, “Are Industrial Country Consumption Risks Globally Diversified?,” in Leonardo Leiderman and Assaf Razin, eds., Capital Mobility: The Impact on Consumption, Investment, and Growth, New York: Cambridge University Press, 1994.

Ostergaard, Charlotte, Bent Sørensen, and Oved Yosha, "Consumption and Aggregate Constraints: Evidence from U.S. States and Canadian Provinces,” Journal of Political Economy, June 2002, 110 (3), 634-645.

Pisani-Ferry, Jean, Alexander Italianer, and Roland Lescure, "Stabilization Properties of Budgetary Systems: A Simulation Analysis," in "The Economics of Community Public Finance” European Economy Reports and Studies 5, European Commission, 1993, pp. 511538.

Pitlik, Hans, Günther Schmid, and Harald Strotmann, "Bargaining Power of Smaller States in Germany’s Länderfinanzausgleich 1979-90,” Public Choice 109, 2001, pp. 183-201.

Sørensen, Bent and Oved Yosha, "Federal Insurance of US States: An Empirical Investigation,” in Assaf Razin and Efraim Sadka, eds., Globalization: Public Economics Policy Perspectives, Cambridge: Cambridge University Press, 1997.

Sørensen, Bent and Oved Yosha, "International Risk Sharing and European Monetary Unification,” Journal of International Economics 45, August 1998, pp. 211-238.

Sørensen, Bent and Oved Yosha, "Intranational and International Credit Market Integration: Evidence from Regional Income and Consumption Patterns,” in Gregory Shin and Eric van Wincoop, eds., Intranational Macroeconomics, Cambridge University Press, 2000, chapter 3, pp. 60-75.

Statistisches Bundesamt, Fachserie 14, Finanzen und Steuern, Reihe 4.S.1, Kassenmässige Steuereinnahmen, 1967 bis 1976, W. Kohlhammer Verlag Stuttgart und Mainz, 1977.

Statistisches Bundesamt, Fachserie 14, Finanzen und Steuern, Reihe 4.S.1, Kassenmässige Steuereinnahmen, 1977 bis 1987, Metzler-Poeschel Verlag Stuttgart, 1989.

Statistisches Bundesamt, Fachserie 14, Finanzen und Steuern, Reihe 4.S.1, Kassenmässige Steuereinnahmen, 1988 bis 1999, Metzler-Poeschel Verlag Stuttgart, 2000.

Statistisches Bundesamt, Fachserie 14, Finanzen und Steuern, Reihe 4, Steuerhaushalt, MetzlerPoeschel Verlag Stuttgart, various years.

Statistisches Landesamt Baden-Württemberg, Arbeitskreis Volkswirtschaftliche Gesamtrechnungen der L“ander, Berechnungstand 1998, electronic copy, 1998.

Statistisches Landesamt Baden-Württemberg, Arbeitskreis Volkswirtschaftliche Gesamtrechnungen der L"ander, Berechnungstand 1998, available online at http://www.vgrdl.de/Arbeitskreis_VGR/home.asp, 2008.

van Wincoop, Eric, “Regional Risk sharing,” European Economic Review 39, 1995, pp. 15451568.

van Wincoop, Eric, "How Big are PotentialWelfare Gains from International Risk sharing?," Journal of International Economics 47, 1999, pp. 109-135.

von Hagen, Jürgen, “Fiscal Arrangements in a Monetary Union - Some Evidence From the US,” in Don Fair and Christian de Boissieux, eds., Fiscal Policy, Taxes, and the Financial System in 
an Increasingly Integrated Europe, Deventer: Kluwer Academic Publishers, 1992, pp. 337359.

von Hagen, Jürgen, "Regional Insurance Against Asymmetric Shocks," in Gregory D. Hess and Eric van Wincoop, eds., Intranational Macroeconomics, Cambridge University Press, 2000.

von Hagen, Jürgen, “Achieving Economic Stabilization by Risk Sharing within Countries,” in Robin Boadway and Anwar A. Shah, eds., Intergovernmental Transfers: Principles and Practice, Washington DC: The World Bank, 2007.

von Hagen, Jürgen and Manfred J.M. Neumann, "Real Exchange Rates Within and Between Currency Areas: How Far Away is EMU?," The Review of Economics and Statistics, May 1994, 76 (2), 236-244. 


\section{Tables}

Table 1: Consumption smoothing in Germany, PCSE regression results, 1970-1994.

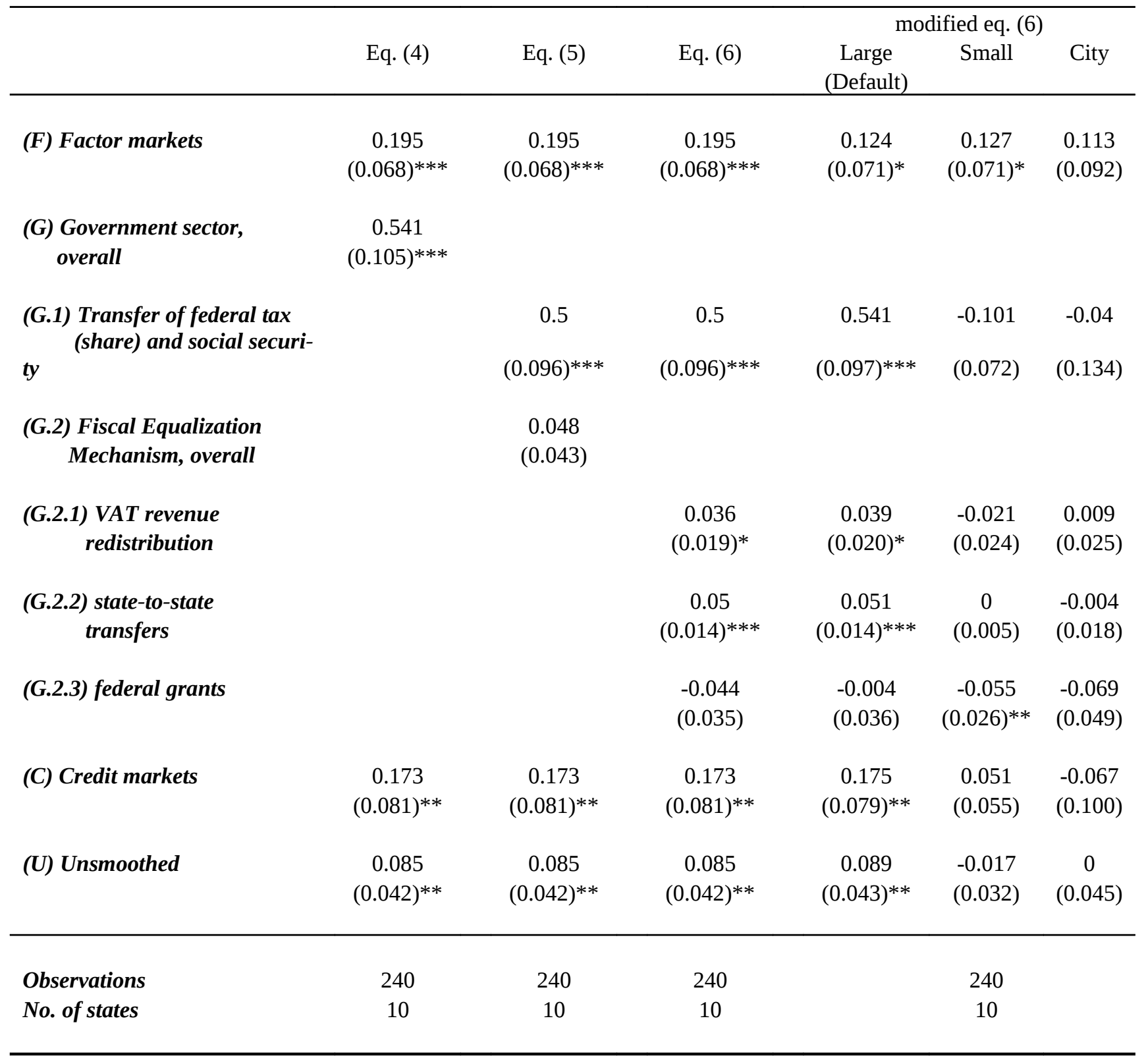

Notes: * significant at 10 percent; ** significant at 5 percent; *** significant at 1 percent. Panel-corrected standard errors are in parentheses, and time-fixed effects are omitted. The sample data consists of all ten West German states (excluding West-Berlin) for the time period 1970 to 1994.

We perform a panel-corrected standard errors (PCSE) estimation controlling for panel-specific heterogeneity, contemporaneous correlation, and common first-order serial correlation. The regression equations for the three columns are described in equations (4), (5), and (6) in the text, respectively. The coefficients describe the consumption smoothing effect of the respective channel listed in the lead column.

The regression results reported in the last three columns are from a modified version of (6) in the text with the added interactive explanatory variables $\Delta \log \left(g d p_{i t}\right) \square$ small $_{i}$ and $\Delta \log \left(g d p_{i t}\right) \square c i t y_{i}$. The coefficients of these interactive terms describe the difference of the consumption smoothing effect of the respective channel for small and city states, respectively, relative to that for large states, listed in column 4. 
Table 2: Consumption smoothing in Germany, PCSE regression results, 1995-2006.

\begin{tabular}{|c|c|c|c|c|}
\hline & Eq. (4) & Eq. (5) & Eq. (6) & $x^{2}$ \\
\hline (F) Factor markets & $\begin{array}{c}0.505 \\
(0.074)^{* * *}\end{array}$ & $\begin{array}{c}0.505 \\
(0.074)^{* * *}\end{array}$ & $\begin{array}{c}0.505 \\
(0.074)^{* * *}\end{array}$ & $\begin{array}{c}2.54 \\
(0.281)\end{array}$ \\
\hline $\begin{array}{l}\text { (G) Government sector, } \\
\text { overall }\end{array}$ & $\begin{array}{c}0.114 \\
(0.072)\end{array}$ & & & $\begin{array}{l}2.35 \\
(0.308)\end{array}$ \\
\hline $\begin{array}{l}\text { (G.1) Transfer of federal tax } \\
\text { (share) and social security }\end{array}$ & & $\begin{array}{c}0.103 \\
(0.059)^{*}\end{array}$ & $\begin{array}{c}0.103 \\
(0.059)^{*}\end{array}$ & $\begin{array}{c}4.48 \\
(0.106)\end{array}$ \\
\hline $\begin{array}{c}\text { (G.2) Fiscal Equalization } \\
\text { Mechanism, overall }\end{array}$ & & $\begin{array}{c}0.02 \\
(0.035)\end{array}$ & & $\begin{array}{c}0.24 \\
(0.889)\end{array}$ \\
\hline $\begin{array}{l}\text { (G.2.1) VAT revenue } \\
\text { redistribution }\end{array}$ & & & $\begin{array}{c}0.008 \\
(0.024)\end{array}$ & $\begin{array}{c}0.1 \\
(0.952)\end{array}$ \\
\hline $\begin{array}{c}\text { (G.2.2) state-to-state } \\
\text { transfers }\end{array}$ & & & $\begin{array}{c}0.008 \\
(0.013)\end{array}$ & $\begin{array}{c}5.64 \\
(0.060)^{*}\end{array}$ \\
\hline (G.2.3) federal grants & & & $\begin{array}{l}-0.001 \\
(0.029)\end{array}$ & $\begin{array}{c}4.24 \\
(0.120)\end{array}$ \\
\hline (C) Credit markets & $\begin{array}{c}0.175 \\
(0.056)^{* * *}\end{array}$ & $\begin{array}{c}0.175 \\
(0.056)^{* * *}\end{array}$ & $\begin{array}{c}0.175 \\
(0.056)^{* * *}\end{array}$ & $\begin{array}{c}0.78 \\
(0.676)\end{array}$ \\
\hline (U) Unsmoothed & $\begin{array}{c}0.208 \\
(0.069)^{* * *}\end{array}$ & $\begin{array}{c}0.208 \\
(0.069)^{* * *}\end{array}$ & $\begin{array}{c}0.208 \\
(0.069)^{* * *}\end{array}$ & $\begin{array}{c}0.99 \\
(0.610)\end{array}$ \\
\hline $\begin{array}{l}\text { Observations } \\
\text { No. of states }\end{array}$ & $\begin{array}{c}176 \\
16\end{array}$ & $\begin{array}{c}176 \\
16\end{array}$ & $\begin{array}{c}176 \\
16\end{array}$ & \\
\hline
\end{tabular}

Notes: * significant at 10 percent; ** significant at 5 percent; *** significant at 1 percent. Panel-corrected standard errors are in parentheses, and time-fixed effects are omitted. The sample data consists of all 16 German states for the time period from 1995 to 2006.

We perform a panel-corrected standard errors (PCSE) estimation controlling for panel-specific heterogeneity, contemporaneous correlation, and common first-order serial correlation. The regression equations for the three columns are described in equations (4), (5), and (6) in the text, respectively. The coefficients describe the consumption smoothing effect of the respective channel listed in the lead column.

The $x^{2}$-statistic reported in the last column tests the joint significance of the added interactive explanatory variables $\Delta \log \left(g d p_{i t}\right) \square s m a l l_{i}$ and $\Delta \log \left(g d p_{i t}\right) \square c i t y_{i}$ included into a modified version of (6) in the text. Its p-value is reported in parentheses. If we get a significant statistic, then the respective smoothing channel for small and city states together is different from that of large states. 
Table 3: Consumption smoothing in Germany, PCSE regression results, 1995-2006, East Germany.

\begin{tabular}{|c|c|c|c|c|}
\hline & Eq. (4) & Eq. (5) & Eq. (6) & $x^{2}$ \\
\hline (F) Factor markets & $\begin{array}{c}0.345 \\
(0.105)^{* * *}\end{array}$ & $\begin{array}{c}0.345 \\
(0.105)^{* * *}\end{array}$ & $\begin{array}{c}0.345 \\
(0.105)^{* * *}\end{array}$ & $\begin{array}{c}0.21 \\
(0.646)\end{array}$ \\
\hline $\begin{array}{l}\text { (G) Government sector, } \\
\text { overall }\end{array}$ & $\begin{array}{c}0.198 \\
(0.086)^{* *}\end{array}$ & & & $\begin{array}{c}0.35 \\
(0.553)\end{array}$ \\
\hline $\begin{array}{l}\text { (G.1) Transfer of federal tax } \\
\text { (share) and social security }\end{array}$ & & $\begin{array}{c}0.121 \\
(0.078)\end{array}$ & $\begin{array}{c}0.121 \\
(0.078)\end{array}$ & $\begin{array}{c}0.1 \\
(0.749)\end{array}$ \\
\hline $\begin{array}{c}\text { (G.2) Fiscal Equalization } \\
\text { Mechanism, overall }\end{array}$ & & $\begin{array}{c}0.076 \\
(0.025)^{* * *}\end{array}$ & & $\begin{array}{c}1.83 \\
(0.177)\end{array}$ \\
\hline $\begin{array}{l}\text { (G.2.1) VAT revenue } \\
\text { redistribution }\end{array}$ & & & $\begin{array}{c}0.05 \\
(0.024)^{* *}\end{array}$ & $\begin{array}{c}4.33 \\
(0.038)^{* *}\end{array}$ \\
\hline $\begin{array}{c}\text { (G.2.2) state-to-state } \\
\text { transfers }\end{array}$ & & & $\begin{array}{c}0.021 \\
(0.017)\end{array}$ & $\begin{array}{c}0.11 \\
(0.742)\end{array}$ \\
\hline (G.2.3) federal grants & & & $\begin{array}{c}0.005 \\
(0.006)\end{array}$ & $\begin{array}{c}0.75 \\
(0.388)\end{array}$ \\
\hline (C) Credit markets & $\begin{array}{c}0.178 \\
(0.069)^{* *}\end{array}$ & $\begin{array}{c}0.178 \\
(0.069)^{* *}\end{array}$ & $\begin{array}{c}0.178 \\
(0.069)^{* *}\end{array}$ & $\begin{array}{c}1.51 \\
(0.220)\end{array}$ \\
\hline (U) Unsmoothed & $\begin{array}{c}0.244 \\
(0.099)^{* *}\end{array}$ & $\begin{array}{c}0.244 \\
(0.099)^{* *}\end{array}$ & $\begin{array}{c}0.244 \\
(0.099)^{* *}\end{array}$ & $\begin{array}{c}0.88 \\
(0.348)\end{array}$ \\
\hline $\begin{array}{l}\text { Observations } \\
\text { No. of states }\end{array}$ & $\begin{array}{c}66 \\
6\end{array}$ & $\begin{array}{c}66 \\
6\end{array}$ & $\begin{array}{c}66 \\
6\end{array}$ & \\
\hline
\end{tabular}

Notes: * significant at 10 percent; ** significant at 5 percent; *** significant at 1 percent. Panel-corrected standard errors are in parentheses, and time-fixed effects are omitted. The sample data consists of the five East German states and Berlin for the time period 1995 to 2006.

We perform a panel-corrected standard errors (PCSE) estimation controlling for panel-specific heterogeneity, contemporaneous correlation, and common first-order serial correlation. The regression equations for columns the three columns are described in equations (4), (5), and (6) in the text, respectively. The coefficients describe the consumption smoothing effect of the respective channel listed in the lead column. The $x^{2}$-statistic reported in the last column tests the joint significance of the added interactive explanatory variables $\Delta \log \left(g d p_{i t}\right) \square s m a l l_{i}$ and $\Delta \log \left(g d p_{i t}\right) \square c i t y_{i}$ included into a modified version of (6) in the text. Its p-value is reported in parentheses. If we get a significant statistic, then the respective smoothing channel for small and city states together is different from that of large states. 
Table 4: Consumption smoothing in Germany, PCSE regression results, 1995-2006, West Germany.

\begin{tabular}{|c|c|c|c|c|}
\hline & Eq. (4) & Eq. (5) & Eq. (6) & $x^{2}$ \\
\hline (F) Factor markets & $\begin{array}{c}0.632 \\
(0.110)^{* * *}\end{array}$ & $\begin{array}{c}0.632 \\
(0.110)^{* * *}\end{array}$ & $\begin{array}{c}0.632 \\
(0.110)^{* * *}\end{array}$ & $\begin{array}{c}1.71 \\
(0.426)\end{array}$ \\
\hline $\begin{array}{l}\text { (G) Government sector, } \\
\text { overall }\end{array}$ & $\begin{array}{c}0.167 \\
(0.097)^{*}\end{array}$ & & & $\begin{array}{c}3.54 \\
(0.171)\end{array}$ \\
\hline $\begin{array}{l}\text { (G.1) Transfer of federal tax } \\
\text { (share) and social security }\end{array}$ & & $\begin{array}{c}0.139 \\
(0.060)^{* *}\end{array}$ & $\begin{array}{c}0.139 \\
(0.060)^{* *}\end{array}$ & $\begin{array}{c}4.08 \\
(0.130)\end{array}$ \\
\hline $\begin{array}{c}\text { (G.2) Fiscal Equalization } \\
\text { Mechanism, overall }\end{array}$ & & $\begin{array}{c}0.044 \\
(0.057)\end{array}$ & & $\begin{array}{c}2.35 \\
(0.309)\end{array}$ \\
\hline $\begin{array}{l}\text { (G.2.1) VAT revenue } \\
\text { redistribution }\end{array}$ & & & $\begin{array}{l}-0.003 \\
(0.035)\end{array}$ & $\begin{array}{c}3.39 \\
(0.184)\end{array}$ \\
\hline $\begin{array}{c}\text { (G.2.2) state-to-state } \\
\text { transfers }\end{array}$ & & & $\begin{array}{c}0.005 \\
(0.025)\end{array}$ & $\begin{array}{c}6.44 \\
(0.040)^{* *}\end{array}$ \\
\hline (G.2.3) federal grants & & & $\begin{array}{c}0.035 \\
(0.031)\end{array}$ & $\begin{array}{c}1.18 \\
(0.555)\end{array}$ \\
\hline (C) Credit markets & $\begin{array}{c}0.083 \\
(0.063)\end{array}$ & $\begin{array}{c}0.083 \\
(0.063)\end{array}$ & $\begin{array}{c}0.083 \\
(0.063)\end{array}$ & $\begin{array}{c}0.71 \\
(0.700)\end{array}$ \\
\hline (U) Unsmoothed & $\begin{array}{c}0.134 \\
(0.072)^{*}\end{array}$ & $\begin{array}{c}0.134 \\
(0.072)^{*}\end{array}$ & $\begin{array}{c}0.134 \\
(0.072)^{*}\end{array}$ & $\begin{array}{c}0.91 \\
(0.633)\end{array}$ \\
\hline $\begin{array}{l}\text { Observations } \\
\text { No. of states }\end{array}$ & $\begin{array}{c}110 \\
10\end{array}$ & $\begin{array}{c}110 \\
10\end{array}$ & $\begin{array}{c}110 \\
10\end{array}$ & \\
\hline
\end{tabular}

Notes: * significant at 10 percent; ** significant at 5 percent; *** significant at 1 percent. Panel-corrected standard errors are in parentheses, and time-fixed effects are omitted. The sample data consists of the ten West German states (excluding Berlin) for the time period 1995 to 2006.

We perform a panel-corrected standard errors (PCSE) estimation controlling for panel-specific heterogeneity, contemporaneous correlation, and common first-order serial correlation. The regression equations for the three columns are described in equations (4), (5), and (6) in the text, respectively. The coefficients describe the consumption smoothing effect of the respective channel listed in the lead column.

The $\chi^{2}$-statistic reported in the last column tests the joint significance of the added interactive explanatory variables $\Delta \log \left(g d p_{i t}\right) \square s m a l l_{i}$ and $\Delta \log \left(g d p_{i t}\right) \square c i t y_{i}$ included into a modified version of (6) in the text. Its p-value is reported in parentheses. If we get a significant statistic, then the respective smoothing channel for small and city states together is different from that of large states. 
Table 5: German states in the sample.

\begin{tabular}{ll}
\hline \multicolumn{1}{c}{ West } & \multicolumn{1}{c}{ East } \\
\hline & \\
Bayern & Berlin (C) \\
Baden-Wuerttemberg & Brandenburg (S) \\
Bremen (C) & Mecklenburg-Vorpommern (S) \\
Hamburg (C) & Sachsen (S) \\
Hessen & Sachsen-Anhalt (S) \\
Niedersachsen & Thüringen (S) \\
Nordrhein-Westfalen & \\
Rheinland-Pfalz (S) & \\
Saarland (S) & \\
Schleswig-Holstein (S) & \\
& \\
\hline
\end{tabular}

Notes: $C$ indicates a city state, and $S$ indicates a small state. 
Table 6: Descriptive statistics, West Germany, 1970-2005.

\begin{tabular}{|c|c|c|c|c|c|c|c|c|c|c|c|c|}
\hline Variable & Year & Mean & $\begin{array}{l}\text { Standard } \\
\text { deviation }\end{array}$ & $\begin{array}{c}\text { Coeff. of } \\
\text { variation }\end{array}$ & Minimum & Maximum & Year & Mean & $\begin{array}{l}\text { Standard } \\
\text { deviation }\end{array}$ & $\begin{array}{c}\text { Coeff. of } \\
\text { variation }\end{array}$ & Minimum & Maximum \\
\hline Gross state product & 1970 & 13548.97 & 3604.77 & 0.266 & 10673.85 & 22174.13 & 1991 & 22916.64 & 4669.97 & 0.204 & 18889.94 & 33844.66 \\
\hline State income & & 14195.53 & 5408.07 & 0.381 & 10272.94 & 27717.71 & & 22334.62 & 5292.63 & 0.237 & 16672.55 & 35536.75 \\
\hline Disp. state income & & 9680.46 & 1207.81 & 0.125 & 8586.92 & 12747.43 & & 16412.53 & 1869.38 & 0.114 & 13905.00 & 19793.93 \\
\hline State consumption & & 9232.39 & 713.70 & 0.077 & 8503.96 & 10919.47 & & 16086.26 & 1614.45 & 0.100 & 13977.14 & 18900.09 \\
\hline Private consumption & & 6732.17 & 548.29 & 0.081 & 6164.64 & 7989.94 & & 12170.55 & 1343.16 & 0.110 & 10240.42 & 14510.24 \\
\hline Public consumption & & 2500.23 & 173.34 & 0.069 & 2339.32 & 2929.53 & & 3915.72 & 308.87 & 0.079 & 3627.95 & 4565.05 \\
\hline Gross state product & 1975 & 15001.89 & 3875.11 & 0.258 & 11941.16 & 24355.12 & 1995 & 22740.56 & 4796.40 & 0.211 & 18551.15 & 34143.84 \\
\hline State income & & 15643.49 & 5741.14 & 0.367 & 11547.85 & 30235.45 & & 22271.77 & 5381.75 & 0.242 & 16978.89 & 36571.74 \\
\hline Disp. state income & & 11280.04 & 1203.68 & 0.107 & 10368.64 & 14442.25 & & 16242.27 & 1620.42 & 0.100 & 14780.63 & 19329.11 \\
\hline State consumption & & 10862.22 & 741.42 & 0.068 & 10123.68 & 12655.37 & & 16565.35 & 1318.65 & 0.080 & 15090.17 & 19047.98 \\
\hline Private consumption & & 7809.03 & 518.61 & 0.066 & 7262.19 & 9072.72 & & 12602.01 & 1011.13 & 0.080 & 11289.47 & 14521.36 \\
\hline Public consumption & & 3053.18 & 244.82 & 0.080 & 2835.29 & 3582.65 & & 3963.33 & 345.01 & 0.087 & 3700.50 & 4665.99 \\
\hline Gross state product & 1980 & 17673.53 & 4488.72 & 0.254 & 14222.43 & 28444.22 & 2000 & 24919.32 & 5473.76 & 0.220 & 19765.83 & 37107.45 \\
\hline State income & & 18426.57 & 6549.82 & 0.355 & 13727.72 & 35102.05 & & 24431.72 & 5803.83 & 0.238 & 19423.52 & 39535.30 \\
\hline Disp. state income & & 13105.81 & 1142.96 & 0.087 & 12154.33 & 16162.29 & & 17748.26 & 1782.84 & 0.100 & 15916.67 & 21261.20 \\
\hline State consumption & & 12768.21 & 822.37 & 0.064 & 11842.75 & 14735.18 & & 17893.22 & 1515.84 & 0.085 & 16569.72 & 20703.39 \\
\hline Private consumption & & 9286.62 & 549.91 & 0.059 & 8667.08 & 10660.09 & & 13624.23 & 1165.07 & 0.086 & 12605.19 & 15667.04 \\
\hline Public consumption & & 3481.59 & 321.58 & 0.092 & 3175.68 & 4075.09 & & 4269.00 & 378.59 & 0.089 & 3934.80 & 5036.35 \\
\hline Gross state product & 1985 & 18860.98 & 4985.44 & 0.264 & 14963.99 & 31491.15 & 2005 & 25445.96 & 5669.02 & 0.223 & 19898.94 & 37675.02 \\
\hline State income & & 19293.36 & 6913.266 & 0.358 & 13970.42 & 37195.14 & & 24797.98 & 6409.94 & 0.258 & 19454.33 & 41941.95 \\
\hline Disp. state income & & 13692.17 & 1089.948 & 0.080 & 12343.83 & 16390.16 & & 18168.76 & 1764.28 & 0.097 & 16359.13 & 22079.05 \\
\hline State consumption & & 13350.56 & 785.799 & 0.059 & 12427.21 & 15194.87 & & 18183.98 & 1679.63 & 0.092 & 16600.94 & 22124.22 \\
\hline Private consumption & & 9613.24 & 514.107 & 0.053 & 8993.64 & 10769.54 & & 13893.85 & 1456.71 & 0.105 & 12623.33 & 17240.65 \\
\hline Public consumption & & 3737.33 & 351.484 & 0.094 & 3433.57 & 4425.333 & & 4290.12 & 247.29 & 0.058 & 3977.61 & 4883.57 \\
\hline
\end{tabular}


Table 7: Descriptive statistics, Germany, 1995-2006.

\begin{tabular}{|c|c|c|c|c|c|c|}
\hline Variable & Year & Mean & $\begin{array}{c}\text { Standard } \\
\text { deviation }\end{array}$ & $\begin{array}{l}\text { Coefficient } \\
\text { of variation }\end{array}$ & Minimum & Maximum \\
\hline Gross state product & 1991 & 17755.29 & 8208.17 & 0.462 & 6625.18 & 33844.66 \\
\hline State income & & . & . & . & . & . \\
\hline Disp. state income & & . & . & . & . & . \\
\hline State consumption & & 13962.63 & 3409.85 & 0.244 & 9051.41 & 18900.09 \\
\hline Private consumption & & 10359.05 & 2841.70 & 0.274 & 6203.64 & 14510.24 \\
\hline Public consumption & & 3603.59 & 599.83 & 0.166 & 2725.53 & 4565.05 \\
\hline Gross state product & 1995 & 18965.38 & 6594.56 & 0.348 & 10641.35 & 34143.84 \\
\hline State income & & 18229.39 & 7115.22 & 0.390 & 9487.89 & 36571.74 \\
\hline Disp. state income & & 14442.59 & 2923.56 & 0.202 & 10465.30 & 19329.11 \\
\hline State consumption & & 15176.36 & 2393.35 & 0.158 & 11849.49 & 19047.98 \\
\hline Private consumption & & 11054.79 & 2399.88 & 0.217 & 7582.12 & 14521.36 \\
\hline Public consumption & & 4121.57 & 386.14 & 0.094 & 3700.50 & 5011.48 \\
\hline Gross state product & 2000 & 20766.21 & 7176.32 & 0.346 & 12169.30 & 37107.45 \\
\hline State income & & 19844.47 & 7767.56 & 0.391 & 10422.15 & 39535.30 \\
\hline Disp. state income & & 15861.06 & 2984.34 & 0.188 & 11857.91 & 21261.20 \\
\hline State consumption & & 16427.13 & 2430.62 & 0.148 & 13239.09 & 20703.39 \\
\hline Private consumption & & 12070.13 & 2352.54 & 0.195 & 8789.37 & 15667.04 \\
\hline Public consumption & & 4357.01 & 376.46 & 0.086 & 3934.80 & 5184.60 \\
\hline Gross state product & 2005 & 21325.95 & 7132.18 & 0.334 & 13208.54 & 37675.02 \\
\hline State income & & 20112.34 & 8079.85 & 0.402 & 10749.65 & 41941.95 \\
\hline Disp. state income & & 16195.63 & 3026.86 & 0.187 & 12028.27 & 22079.05 \\
\hline State consumption & & 16535.92 & 2660.94 & 0.161 & 13166.74 & 22124.22 \\
\hline Private consumption & & 12218.94 & 2566.29 & 0.210 & 8875.94 & 17240.65 \\
\hline Public consumption & & 4316.97 & 271.92 & 0.063 & 3977.61 & 5006.38 \\
\hline
\end{tabular}

Note: The means of the variables in the table are calculated as unweighted means. All numbers are expressed in 1991 euros. 
Table 8: Descriptive statistics, East Germany, 1995-2006.

\begin{tabular}{|c|c|c|c|c|c|c|}
\hline Variable & Year & Mean & $\begin{array}{c}\text { Standard } \\
\text { deviation }\end{array}$ & $\begin{array}{l}\text { Coefficient } \\
\text { of variation }\end{array}$ & Minimum & Maximum \\
\hline Gross state product & 1991 & 9153.04 & 4559.52 & 0.498 & 6625.18 & 18427.46 \\
\hline State income & & . & . & . & . & \\
\hline Disp. state income & & & & & & \\
\hline State consumption & & 10423.25 & 2477.35 & 0.238 & 9051.41 & 15456.55 \\
\hline Private consumption & & 7339.88 & 1864.65 & 0.254 & 6203.64 & 11108.34 \\
\hline Public consumption & & 3083.37 & 622.94 & 0.202 & 2725.53 & 4348.21 \\
\hline Gross state product & 1995 & 12673.42 & 3611.69 & 0.285 & 10641.35 & 19981.02 \\
\hline State income & & 11492.07 & 3548.75 & 0.309 & 9487.89 & 18641.37 \\
\hline Disp. state income & & 11443.11 & 1908.23 & 0.167 & 10465.30 & 15317.31 \\
\hline State consumption & & 12861.39 & 1940.36 & 0.151 & 11849.49 & 16805.54 \\
\hline Private consumption & & 8476.09 & 1634.18 & 0.193 & 7582.12 & 11794.06 \\
\hline Public consumption & & 4385.30 & 315.45 & 0.072 & 4173.13 & 5011.48 \\
\hline Gross state product & 2000 & 13844.36 & 2928.48 & 0.212 & 12169.30 & 19794.40 \\
\hline State income & & 12199.05 & 2853.83 & 0.234 & 10422.15 & 17924.78 \\
\hline Disp. state income & & 12715.73 & 1415.17 & 0.111 & 11857.91 & 15570.90 \\
\hline State consumption & & 13983.64 & 1457.41 & 0.104 & 13239.09 & 16952.41 \\
\hline Private consumption & & 9479.96 & 1130.88 & 0.119 & 8789.37 & 11767.81 \\
\hline Public consumption & & 4503.68 & 354.77 & 0.079 & 4177.84 & 5184.60 \\
\hline Gross state product & 2005 & 14459.28 & 2055.59 & 0.142 & 13208.54 & 18549.27 \\
\hline State income & & 12302.94 & 2190.90 & 0.178 & 10749.65 & 16654.78 \\
\hline Disp. state income & & 12907.09 & 1057.76 & 0.082 & 12028.27 & 14978.74 \\
\hline State consumption & & 13789.15 & 1295.31 & 0.094 & 13166.74 & 16428.22 \\
\hline Private consumption & & 9427.42 & 988.04 & 0.105 & 8875.94 & 11421.84 \\
\hline Public consumption & & 4361.73 & 328.48 & 0.075 & 4124.56 & 5006.38 \\
\hline
\end{tabular}

Note: The means of the variables in the table are calculated as unweighted means . All numbers are expressed in 1991 euros. 